\title{
On the Spirit of Harmony in the Poems of Han Shan and Its Modern Education Enlightenment
}

\author{
Yang Xiaohui, Zhao Haomai and Zhu Pengxuan \\ (Xi'an University, Shaanxi Normal University, Xi'an Tieyi Binhe school, Shaanxi, 710065)
}

Keywords: Han Shan poetry; The spirit of harmony; Modern Enlightenment

\begin{abstract}
In the Tang Dynasty, Han Shan's Han monk left over three hundred poems which are fresh and refined, peculiar in style and rich in content. Since the Song Dynasty, these poems have had a widespread influence, and have gone abroad for the lead and surpassed many famous poets in the Tang Dynasty. Throughout Hanshan's poems, we can easily find that there are many cultural connotations in these poems. The spirit of harmony is the essence of Hanshan's poetry and the main reason for its work to circulate. Even today, this spirit of harmony has great inspiration for us.

"Harmony" refers to cooperation and harmony. On the one hand, it means the harmony between human and nature, and also called the theory that "Man is an integral part of nature"; on the other hand, it means the harmony between man and man, man and society, and also called "Harmony is precious". "Harmony" is the core value of Confucian humanism. Confucius said: "Courtesy purposes, and for your". ${ }^{[2]} 8$ The spirit of harmony of " Things which have negative yin-yang, salt air and that" ${ }^{, 3]}$ comes from Taoism. Only through "Harmony", the universe can be integrated, so that two aspects in a contradiction can be balanced and eventually relatively stable development can be achieved.

Since the Song Dynasty, the Hanshan poems were widely spreading and popular overseas. Throughout the Hanshan poems, its core factor is the harmony culture. Until nowadays, the spirit of harmony plays a great enlightening role to us.
\end{abstract}

\section{Unity and Peace of Mind, Self-Cultivation}

Firstly, the harmony spirit of Hanshan poems is embodied in the harmony between self and mind. He settled privately on the cold rock of the Tiantai Mountain for most of his life. In Hanshan poems, there are a lot of verses that indicate the relationship between body and mind. "People are based on the body, and body is controlled by heart. Body is inside the heart, and once the soul is evil, the flesh will also fall apart." ${ }^{\text {[4] 278-279 }}$ Body is the origin of human beings, and it is the mind that controls the human body. When the body is alive in the world, the heart must be pure. Once the soul is evil, the flesh will also fall apart. Which means, it is the "Body" as the material basis that people can settle down, and "Heart" leads the "Body". Both of them are not only interdependent but also mutual restraint. Although the body is the material foundation, it needs the heart control. However, the heart can't replace the body's action. Whether a person is kind or not depends on whether there is the kindness. Once there is the kindness, the body would do good deeds. If the intention is not right, the body will fall apart. This is the same meaning with the old sayings of unjust is doomed to destruction. Only there is the harmony between body and mind, people will not be panic, and always remain invincible. The mind is pure without evil thoughts, then people themselves will naturally be peaceful and calm.

"If mind is not confused by material things, and the evil will not be brought forth. If the mind is pure, then people will be free from troubles." "4] 598-599 Hanshan believes that the human minds should not be seduced by all kinds objects outside, and the real self achievement should be obtained by the way of any foreign objects. If there are any expectations, then it is delusion. Only when thoughts and minds are released from desires, people could obtain the real freedom. This is what Hanshan wants to achieve, the harmony between body and mind. Therefore, how about the heart, which controls the body. He said: "My heart is like the autumn moon, and the green pool is clear and clean, and nothing is comparable..." ${ }^{[4] 102-103}$ Here, the autumn moon and green pool he applied 
indicates the free heart and mind, and it was clear and innocent. Hanshan treats everything in the world with stoicism. Its self heart is bright and clear like autumn moons, pure and crystal as green pool. However, in real life, there are ups and downs like the gloom of the moon all the time, the wax and wane, the gloom, and ups and downs are the norms of life. The green pool can also be dry, full and has limits. It is quite praiseworthy for people to maintain a perfect, comfortable, and detached heart in the interference of foreign objects. There is nothing in the world that can be compared with the peace and tranquility of the soul. "My heart is like the autumn moon, the green pool is clear and clean" is the highest state of mind and body that exactly the Hanshan want to achieve!

Hanshan poems contain a lot of verses about harmony between body and mind. "If the mind free then your body is also self-clearing. The holes contain a lot of mysteries. Because it refers to the moon, the moon is key part of the heart." [4] 560-561 "In the morning, the shadow of white clouds are still. At night, the shadow of bright moonlight floating on the river. There is no dirt on the body, and the heart is more worried." [4] 568-569 "Anyone read my poet, their hearts must be protected and clean. If they are greedy for the future, they may be do everything immediately to please others. Getting rid of evil karma, returning to true yourself." ${ }^{[5]}$ The poet applies the natural things such as the moon and white clouds to indicate the succinctness of the self-sufficiency, and the clearness of the mind, the inner peace, and the absence of grime are the ideal realms of the harmony between Hanshan body and mind.

Although the era in Hanshan is different from where we live, the spirit of body and mind harmony he seeks are everlasting. The faster the pace development of the times, the more our mind and body are eager to return to a state of peace. Therefore, people should keep on the self-cultivation, to pure their minds, and just like the sayings of "My heart is like the autumn moon, the green pool is clear and clean." This is the best inspiration for people from Hanshan. With all kinds of pressures in life and work, although we can't leave behind the vulgar and retire from the world like Hanshan, we can accept the thoughts from Hanshan to pursue the body and mind harmony. Life itself is like a religious doctrine, how to resolve the contradiction between body and mind, how to achieve the unity of knowing and doing, how to maintain relative stability in the struggle between the self-consciousness and the external material world. To maintain the body and mind harmony is the only solution to this series of problems. Only in this way can the mind be clear without evil, and people will naturally be calm and peaceful, and the body and mind will be clear and healthy.

\section{Interpersonal Relationship and Group Harmony, Cooperation and Mutual Benefits}

There is always the relationship between others and society in their lifetime. The interpersonal skill determines the living conditions of people. How to deal with these relations, Hanshan has his own understanding, the spirit of harmony.

Before the seclusion in Tiantai Mountain, Hanshan had a happy country life. "The family picked up the mountain fruit with children, and the couple do the farm work together. What's the family have? Only a bed with books." "4] 54-55 That is, though his early years were quite normal, there is the harmony, joy and extraordinary refined in normal. Besides farming, enjoying the family fun, it also has books. Although the affluence is not good, he is self-satisfied with joy and full of spirit.

This farming life is the most traditional, natural and harmonious lifestyle in China. There are some similarities between the harmonious life and family, and the quiet and natural lifestyle mentioned in the poem, and quiet and simple mind state of seclusion stand aloof from worldly success of Tao Yuanming's "Stagnation in the human world, without car and horse."

"Parents have a lot of books and always read books regardless of time, with the pastoral happiness and not enviable of the wealth of others. The woman works on the loom with the machine sounds. The child plays with joy. Clapping with enjoying the butterfly and listening to the bird songs. Who will come to congratulate, the hacker visits repeatedly."[4]30-31 "Brothers come from five counties, fathers and sons in the three states ... dreaming picking up the melons, oranges. How to switch the messages in the country, just like the fish that comes from the river." ${ }^{[4]}{ }^{12-13}$ The 
family is happy and harmonious.

In addition with small families, there is also harmonious of Hanshan with its neighbors. "In hot summer, who will come to drink and chat with me? All kinds of wild fruits picked from mountains, bulrush are applied as mats, and the banana leaves are applied as plates, which are placed casually. After the revelry, the front tall Xumi Mountain is also like a tiny one., ${ }^{[4] 238-239}$ On the hot summer, coming back with some water and drinks, taking up the drinks and chatting merrily with your neighbors. All kinds of wild fruits picked from mountains, bulrush are applied as mats, and the banana leaves are applied as plates, which are placed casually. After the revelry, the front tall Xumi Mountain is also like a tiny one. "Whoever comes to celebrate, hackers have passed by." This kind of harmonious relationship with relatives and others is pleasant and beautiful. The value orientation he passed on to the world, attaching great importance to family harmony, brothers and friends' harmony, is this not the ideal living environment for us today?

In Hanshan poems, the harmonious relationship also indicates the children's education. This can be seen from the education he advocates for raising children and paying attention to them. "If your child do not have a teacher, then the children will grow up that are not as knowledgeable as the rats in the pavilion. Where are the knowledgeable teachers, you can learn from elders. It's better to choose a good friend. In May, people will laugh at to sell fresh fish." [4]440-4419 Hanshan believes that it is necessary for parents to provide their children with education. If a family raise the children without offering them with education, the children will grow up that are not as knowledgeable as the rats in the pavilion. For the children will never receive the opportunity to contact the eminent elders without the education. From this, he said that parenting must attach great importance to education. A happy family means wealth is always the faith for Chinese people, and children are the hope of a family, and also the most important link for family harmony. If a child brought up by a family like a "Rat" or even worse than a "Rat", the consequences are clear, and let alone the family and everything? Just like the mother of Mencius removed three times in order to reach a desirable neighbourhood, Hanshan believes that it is necessary to provide a healthy environment for children to grow up when raising children. The so-called with the good, it becomes good; with the evils, it becomes evil, and it is one thought moment between good and evil. He also takes the selling fish for example, it shows that the external environment is crucial to human development. His poems convey the relationship between family harmony and the education of their children.

People are not alone in the society. There are different levels of intersection between relatives, friends, colleagues, and even strangers with us in life. How to deal with the interpersonal relationship, Hanshan clearly states its own opinion about harmonious interpersonal relationship in his poems, that is, attaching great importance to family harmony and the harmonious relationship with others. This kind of thinking is undoubtedly reasonable in some ways. No one can live by himself and develop in isolation away from the social group. Therefore, maintaining the interpersonal harmony is not only beneficial to the unity and individuals and groups harmony, but also helpful to the peaceful development of the world. Thus, the General Secretary Xi proposed the ideas of "Community with a shared future for mankind". Actually, this idea advocates the cooperation and mutual benefits, common development, and this is naturally the same as the spirit of the Hanshan harmony.

\section{Man and Nature Coexist Harmoniously and Construct the Ecological Civilization}

The rich spiritual world of Hanshan is close with the natural environment in Tiantai Mountain. Being in such a dense and tranquil, peaceful and wonderland-like mountain forest, the poet finally found his soul destination and experienced the spiritual connotation of "The harmony between heaven, earth, and people." Here, Hanshan found the joint point of life and heaven and earth. It is precisely because of this tranquil and peaceful natural environment that Hanshan's material life is bad, however, he can still be able to enjoy it with a happy attitude. Here he feels himself as the friend with the surrounding mountains and rivers, birds, beasts and fish, and he is a part of nature. Thus, Hanshan's body and mind is extremely healthy and open-minded. In Tiantai Mountain, he integrated with nature, Hanshan finally ends his life in an old age without disease. Realizing the 
harmony between man and nature.

"Hanshan is deep, and in my heart. Pure white stone, but it is not gold. Spring sounds, that Boya is playing the Quqin. There is Ziqi who can distinguish this sound." ${ }^{4]}{ }^{620-621}$ In this poem, the deep and serene natural environment quite accords with the author's minds. The poet considers himself as the king of the mountain. There are only clean and worthless white stones, and without gold for the desperate robbing. This natural environment surrounded by bright moons, light breeze, and green mountains is not available for any money. At the moment, we are also responding to the call of the times to protect the nature of the mountains and the green hills. The concept of "Green mountain is Jinshan Yinshan" should become the belief of everyone. In the view of Hanshan, natural mountains and lakes can cleanse the people' hearts. Here, the poet considers himself as Ziqi, and the quiet sound of the spring is like the sound of the fangs. The relationship between Hanshan and the landscape is just like the relationship between Ziqi and Boya. The poet regards the landscape as a intimate and bosom friend. Every day, the poet listens to the singing sound of the natural landscape, and feels the mountain breeze and the tranquility of the mountain forest. I confound whether I am between the mountains and forests, or the mountains and forests are between me. A state of harmony between man and nature is realized

"Hanshan is silent without anyone. The ravine is lonely without birds. The birds are singing, which makes the Hanshan more lonely. The wind blows the face, and the snow is heavy that could bury me. The sunlight is always blocked, the coming of spring is never known." ${ }^{[4]}{ }^{62-63}$ The poem describes that Hanshan road is deep and remote, and the riverside is lonely and cold. In silent winter without anybody, the sound of the birds turns more and more crisp and loud. Braving the wind and snow, in this quiet and deep mountain, the poem has already integrated with the mountains and rivers not knowing the change of sunrise and sunset, the changes of spring, summer, autumn and winter, and has become everlasting as the universe. This state of mind aloof from material things, breaks the boundary between ephemerality and eternity, finiteness and infinity, and the Zen of harmony between man and nature is realized.

"Heavy rock is where I live, and the bird buried the human road. What's in the court, only white clouds and lonely stones. Staying in the house for several years, with the time passes. Sending message to the rich family, the virtual name will be no benefit." [4] 4-5 The poet lived in the rocky area of overlapping high barriers, with the sinister terrain, and nothing in the courtyard, only white clouds surrounding with blue stone. In the primitive natural environment, the poet treats the world with the propensity of tranquil and self-sufficient, and time passes. Dislike any glory and wealth. With tranquil mountains and the sleek white clouds, the nature has already wash all the attachments of poet. Returning to nature, back to the myself, free from undeserved reputation, realize the harmony between man and nature, thus a happy state is achieved. "Since seeing the top of Tiantai roof, it is so tall that there is a little loneliness out of the crowd. The wind shakes the bamboo, and the moon comes out from the sea. Seeing from the mountain, there are white clouds. The natural beauty are the mountains and rivers, and the original ambition is morality and ethics." ${ }^{[4]}{ }^{460-461}$ The natural beauty of Tiantai Mountain enriches the poet's spiritual world, and Hanshan observes the natural landscape with a clear state of mind, and then the harmonious realm of harmony between man and nature is realized

The harmonious coexistence between man and nature is the consensus for nowadays' people. As General Secretary Xi said, "Green mountain is Jinshan Yinshan". This harmonious relationship between man and nature is also highly praised by Hanshan. Hanshan lived in the cold rock of Tiantai Mountain. The surrounding sound of wind, rain, stream, the blue sky and white clouds, flowers and trees, birds and beasts, all consist of pleasant figure of peaceful coexistence between human and nature. "The stone bed is adjacent to the green wetland, and the tigers and deers are always neighboring each other". [4] 586-587 Hanshan takes the blue stone as the bed, and the stone bed is adjacent to the clear water of the mountain. He lives peaceful with tigers and elk. However, this moment, for the sake of vanity and the so-called appearance of "beauty", many people contaminate the environment, abusing animals and destroying the ecology at any cost. Compared with a thousand years ago, this is more despicable that Hanshan . 
In conclusion, Hanshan poems is full of harmonious thoughts. The harmony between the flesh and spirit, between human beings, and the harmony between man and nature is the essence of Hanshan poems. It is the broad and useful revelation in the spirit of harmony that makes Hanshan poems everlasting and widely spreading. In today's society, the pressure on family and work is increasing due to fierce competition. People are rich in material life, however, the pressure on the body and mind is often overloaded. If the physical and mental unity, harmony with people, and nature is achieved, then peace of mind can be realized. The social harmony and stability can be achieved, free from troubles, and the ecological civilization and sustainable development of society can be achieved.

\section{Acknowledgement}

[Fund Project]: National Social Science Fund Project (14XZW015); Shaanxi Provincial Department of Education Humanities and Social Science Base Project (14JZ043); Xi'an Social Science Fund Project (15WL20)

\section{References}

[1] Zuo Qiuming(The Spring and Autumn Period). Spring and Autumn Annals [M]. Shanghai: Shanghai Chinese Classics Publishing House, 1st edition, August 1978, P. 511.

[2] Translated by Zhang Yanying. The Analects of Confucius. Learning[M]. Beijing: Zhonghua Book Company, reprinted in 2007 (Chinese Classic Collection).

[3] Noted by Wang Bi (Wei Dynasty). Collated and annotated by Lou Yulie. Laozi's Morality Notes [M]. Beijing: Zhonghua Book Company, December 2008, P. 117.

[4] Shi Yuanpeng. Appreciation of Hanshan Poems[M]. Beijing: China Social Sciences Publishing House, 1 st edition, December 2003.

[5] Xiang Chu. Hanshan Poem Note[M]. Beijing: Zhonghua Book Company, 1st edition, March 2000, P. 15.

[6] Zhang Liwen. Harmony Introduction and the Study of the 21st Century Cultural Strategy [M]. China Renmin University Press, October 2006, 1st edition.

[7] Qian Xuelie. Bitan Qiushui Yinghanshan_-Hanshan Poems Interpretation[M]. Central Compilation \& Translation Press, September 2009.

[8] Sun Changwu. Zen Thought and Poetry [M]. Zhonghua Book Company, 1997 edition.

[9] Cao Shenggao, Yuan Xiaojing. Fanyin Qingyun: A look of monk poets and painters [M]. Publishing House of Jinan, March 2011. 